\title{
Permatang Pauh by Elections: Analysis Approach Framing Content in the Prime Media Selected
}

\author{
Mohd Hilmi Hamzah ${ }^{1}$, Nur Qurratul' Aini Ismail ${ }^{1}$, Kamarudin Ngah $^{2}$, Jamaludin Mustaffa ${ }^{3}$, Mohd Fitri Abdul \\ Rahman $^{2} \&$ Zaherawati Zakaria ${ }^{4}$ \\ ${ }^{1}$ Centre for Policy Research and International Studies (cenPRIS), University of Science Malaysia (USM), \\ Penang, Malaysia \\ ${ }^{2}$ College of Law, Government and International Studies, Northern University of Malaysia (UUM), Kedah, \\ Malaysia \\ ${ }^{3}$ College of Arts and Sciences Northern University of Malaysia (UUM), Kedah, Malaysia \\ ${ }^{4}$ Faculty of Administrative Science \& Policy Studies, Universiti Teknologi MARA, Kedah, Malaysia \\ Correspondence: Mohd Hilmi Hamzah, P. O Box No. 269, Jalan Desa Bayanmas 6, Taman Desa Bayanmas, \\ 06050, Bandar Bukit Kayu Hitam, Kedah, Malaysia. Tel: 60-17-988-7862. E-mail: h_mamat@yahoo.com
}

Received: October 7, 2013 Accepted: December 13, 2013 Online Published: January 26, 2014

doi:10.5539/ass.v10n4p46 URL: http://dx.doi.org/10.5539/ass.v10n4p46

\begin{abstract}
The concept of media framing in conceptual approach adopted is how a selected issue and ultimately determine what facts should be taken. Formation of news framing is important because it became the starting point on the agenda of the media so that the audience will be wondered how any news is treated to give effect to them. Studies conducted on election Permatang Pauh parliamentary see framing approach to selected newspapers in display issues election. The use of framing approach in reviewing the issues important election for framing approach is able to explain how sub-sub categories news way before the formation of framing a major issue categories. Results showed that framing pattern used in the study election issues could explain how a set of key issues based on the sun-sub categories.
\end{abstract}

Keywords: framing, media and permatang pauh by election

\section{Introduction}

Press is one of the media that already existed many years ago, since man knows how to write and create writing. It cannot be overturned while newspapers still play an important role even though we already tracking of the 20th century's technologically sophisticated. Thus, press is the fastest platform for delivering news and information to the public (Mansor, 1995).

News that featured in the newspapers, television and radio is selected and the information is reported by a specific treatment. In other words, the reporting process involves the selection and editing of information selectively according to various levels. This process is the construction of the media agenda or framing of news. The existence of the media agenda building process is common in the reporting process either framing or priming approach or both. Construction of media agenda is the process of placing an issue on the agenda for the media to get the public agenda achievement taking time and has to go through some processes (Lang \& Lang, 1983).

Formation of news framing is important because the displayed frame can highlight specific problems until its capable of satisfying the community and enable to rise or highlights dissatisfaction among the community (Chang, Musa, Ezhar, Syed Arabi, \& Lim, 2009; Lai \& Lee, 2007; Reese, 2001). According to Chang, Tan and Mohd Zaid (2009), framing messages and media selection is important in planning. This is so because the media are carriers of messages and each message should contain objectives, inputs and markets obviously clear targets so that the selection process or pattern formation is an appropriate media news before its displayed to the public (Chang, Tan, \& Mohd Zaid, 2009). Reese (2001) indicates the formation of news framing must be adopted by the media in knowing how the perspective or point of view form and choose the issues and perspectives that ultimately set the agenda taken and highlighted (Reese, 2001). Framing news pattern often be the starting point 
to the media agenda and the impact of pattern formation will become effective orientation for displaying news reader (Kim, Scheuffele, \& Shanahan, 2002).

In the process of Election Day, the newspaper also has an important role in providing information about news election issues to the audience. According to Taufik (2004), mass media provide clear information about the process of an election itself, either in intent or purpose of the election, until people understand the importance of the meaning of their participation in the elections. According to him, the media in question in this case is that the print media, especially newspapers, has the advantage of a very wide coverage.

Thus we can conclude that the mainstream media and the alternative press play their respective roles in accordance with his duties as a media to inform, persuade and influence voters through a pattern or way of framing the news.

\section{The Concept of Framing Theory}

Frame, a term used in media studies, sociology and psychology, refers to the social construction of a social phenomenon by mass media or political resources or specific or social movement organizations (Gregory, 1972). Framing is to focus the attention of those in the field of meaning. Framing concept is said to have been introduced by Gregory in 1972 (Reese, 2001). At first 'frame' is intended as a conceptual structure for organizing one's outlook in terms of providing the categories to become a reality. 'Framing' is the approach adopted to find out how the perspective or point of view and perspective of choosing issues that ultimately determine what the facts are taken and highlighted (Chang, Tan, \& Mohd Zaid, 2009).

This concept was later developed by Goffman (1974) who assumes the frame pieces that guide the behavior of individuals in read reality. He further adds that efforts in introducing framing approach to making decisions on social and economic matters is said to have founded the theory (Framing Theory) by communication scholars such as Endres (2004), Scheff (2005) and Simon and Xeno (2000). The earliest communication study use framing theory has been done by Tuchman (1978). He used the approach of framing the research content of news reporting perspective. Framing theory suggests that how something is shown to influence individual choices in decision making. Frames affect audience perceptions of news and give the form of agenda-setting as well as also highlight on how to address about the problem. Framing is a communication concept that brings others to accept one meaning and others. The process of this form usually derived the communication resources to define and build a political issue or public controversy (Chong \& Druckman, 2007).

Scheufele and David (2007) reveals (consistent with the tenses in this paper please) that the emergence of agenda setting and framing has marked a paradigm shift of political communication research and is closely related to political issues. According to Bryant and Miron (2004), nowadays, the use of framing theory is an approach applied research in the field of political communication. According to Scheufele (2000), attempted to expand and develop existing theory of agenda setting theory. The research paper is presented in Chicago in August 1997, stated that framing is a paradigm and is considered as the second stage of agenda setting. Agenda setting theory is based on the "assumption on behavior" while framing theory is assumed to be "no significant changes in the words to describe how the situation might cause the audience to interpret this situation" (309).

Research on framing is done by many scholars in recent years (Weaver, 2007). Framing studies are more popular than specification research agenda (Agenda Setting) proposed by McCombs \& Shaw (1972) to study at Chapel Hill in 1968 (Weaver, 2007). Agenda setting theory found to be more easily understood by the transition linearly interests involve three components: the media agenda, the public agenda, and policy agenda (Littlejohn, 2002). Meanwhile, more complicated Framing Theory and until now still in the search for a consensus voice. But this problem can be solved by finding resources that framed the frame up to the description of how a time frame described an impact on society (Littlejohn, 2002).

Framing involves both the creation and understanding of frames simultaneously and communicate information in a process of mediation communications (Chang, Fauziah, \& Wan Amizah, 2009; D'Angelo, 2002; Scheufele, $1999 \& 2000$ ). Framing the media play a role in focusing public attention on a particular issue. Frequency, depth and importance given by the media on certain issues are believed to determine the level of observation, reaction or thoughts of the targeted audience or community in that direction. According to Reese (2001), "Framing is set principles that are socially together and continuously over time". This is consistent with the statements by Weaver (2007) that states the use of framing theory was suitable for the 21 st century due to the formation of news framing will detail and clarify how things shaped up news issues affecting the reader to think and can affect readers. Thus the study focused on framing that featured in the press and provide a qualitative picture broken down by each category are less committed in Malaysia even more involved in the by-election context. 
Previous election study on the use of framing theory done by Melissa, John and Sean (2008) titled Mexican Expatriates Vote? Framing and Agenda Setting in the U.S. News Coverage about Mexico. Content analysis was used as the study method which aims to analyze the issue of framing and second-level agenda issues presented in the U.S. press before the election Mexican presidential election. The results showed 200 articles related to the issue of elections in the U.S. newspaper from August 2005 to mid-April 2006. Findings of the study in terms of the candidates showed more releases featuring Andre's candidate Manuel Lopez Obrador of $59.6 \%$, followed by candidate Roberto Madrazo (27.8\%) and the candidate who won the election, Felipe Calder (29.1\%). In terms of the properties of the highlighted candidate more than a local or Mexico-US and shown that the issues most mocked before the election of horse racing. The main substantive frames are elections as an extension of US-Mexico economic relations and election as a Latin American expansion movement. Expatriate voting law is deemed to be successful and blamed apathetic voters, the Mexican much damage the performance made by the government and a lot of corruption in the government.

Nadeau, Petry and Belanger (2008) have done a research "Strategic Framing Issue in Election Campaigns: The Case of Healthcare in the 2000 Canadian Federal Election". This paper developed theoretical framing strategic issues in election campaigns by stated that different theoretical issues will be led to various conflicting theories in many elections. As a result, the parties fought during the campaigns to increase their popular appeal prioritize frames. This reconciles frames, in certain circumstances, contribute to modify the perceptions voters of the party leaders and election results. The theory is tested with data from the 2000 Canadian federal election. Content analysis of party campaign materials and media coverage shows how successfully the duties Liberals formed frame health issues to officially condemn the opposition's credibility. The results also showed framing strategies based on the analysis of the Liberal Party members contribute to change the election results.

The study conducted by Thomas, Zoe and Rosalee (1997) studied the title Toward a Psychology of Framing Effects looking framing is the process whereby the communication resources to build and define social or political issues for the audience. Previously many political communication scholars have discussed the mass media framing. This study aims to determine the effect of framing theory, especially from a psychological point by way of framing can influence attitudes. This study also discusses the difference between framing and persuasive theory tradition that focuses on changing attitudes audience. Results showed that there is a difference of the results support the hypothesis of appropriate framing compared with traditional seduction theory. The results suggest that the use of framing in political communication can influence voter attitudes as explains to reach the level of understanding of the formation of news.

While in context of Malaysia, previous research using framing theory has been done by Chang and Wan Fauziah Amizah, (2010), a study of the Knowledge of Content Analysis Framing Chedet Weblog. Com. This study aims to identify the prominent source frame is displayed by Tun Dr Mahathir Mohamad through interactive online social media. Empirical Research on weblog content with five measurements general frame formed by Semetkoa nd Valkenburg (2000) allows explanation of the phenomenon of blogging sphere. Clarity frames compared with two different languages and with people and organizations that were targeted in this weblog from May to December 2008. The results showed that both the target languages and have an impact on the clarity of the frame. In addition, the impact of the target size is larger than the language found in the explanation of variance.

Lee and Mohd Safar (2009) done a study entitled A Political Media Framing of Personality: A Case Study of a Malaysian politician. The objective of this study is to show how newspaper featuring photos, personality and reputation of politicians through the pages that are placed in the position of either press down on the main home page or other pages on the news and pictures. This study uses framing theory approach theoretical study to see how 11 newspapers and regional newspapers put the frame related news Datuk Yong Teck Lee, who is a politician from the state. A total of 241 news and newspaper articles Malaysia, English and Mandarin analyzed. In general, this study found that mainstream newspapers and regional newspapers display a different report. There are some newspapers are more likely reflects a negative report against Datuk Yong Teck Lee. While others show him as a Sabahan hero, more positive and neutral. This shows how framing helps news release a role played in strategy and at the same time develop or destroy the political career of a personal reputation. This news frames will help to clarify in detail the formation of a tendency toward issues and news.

\section{Framing Releases in Permatang Pauh By-Election}

The current situation and direction nowadays shows the trend of election news published in newspapers and derived to news broadcast and treatment. The use of theory is crucial to ensure the direction of the election news published meets the current situation that occurred today. Most of the previous studies related to media and election applied on agenda setting theory. However, Weaver (2007) argues that the theory that meets the current 
situation and direction on the issue of election news at present is the framing theory. This argument is further agreed by Chong and Druckman (2007), who argues that framing theory is suitable in studying political issues such as the election and is closely related to political communication. It is because this theory can explain the actual treatment of the issue based on the frame. However, the use of framing theory in the study of electoral issues is still relatively under-utilized (Chong \& Druckman, 2007). Therefore, this study done using framing theory is seen increasingly popular use in the 21 st century in line with the current situation and was suitable for the study of political issues such as elections (Weaver, 2007).

This study was conducted on four selected Malay newspapers by focusing into framing the issues parliamentary election constituency by explaining in detail the pattern formation analysis on key issues 'tree nodes' made using NVivo 8 software. As noted by Kim, Scheuffele and Shanahan (2002) a study should form a new issue because of the implications of the study indicate that the media framing pattern on pattern formation relevancy news and public perception formation. Generally, the analysis showed that there were 11 issues deemed major or very significant (Figure 1). The main issues are the issues of government formation, education, candidates, ethnic, elections, media, ruling party, Pakatan Rakyat, development and security. The 11 key issues developed based on sub-sub categories news way before the formation of framing a major issue categories.

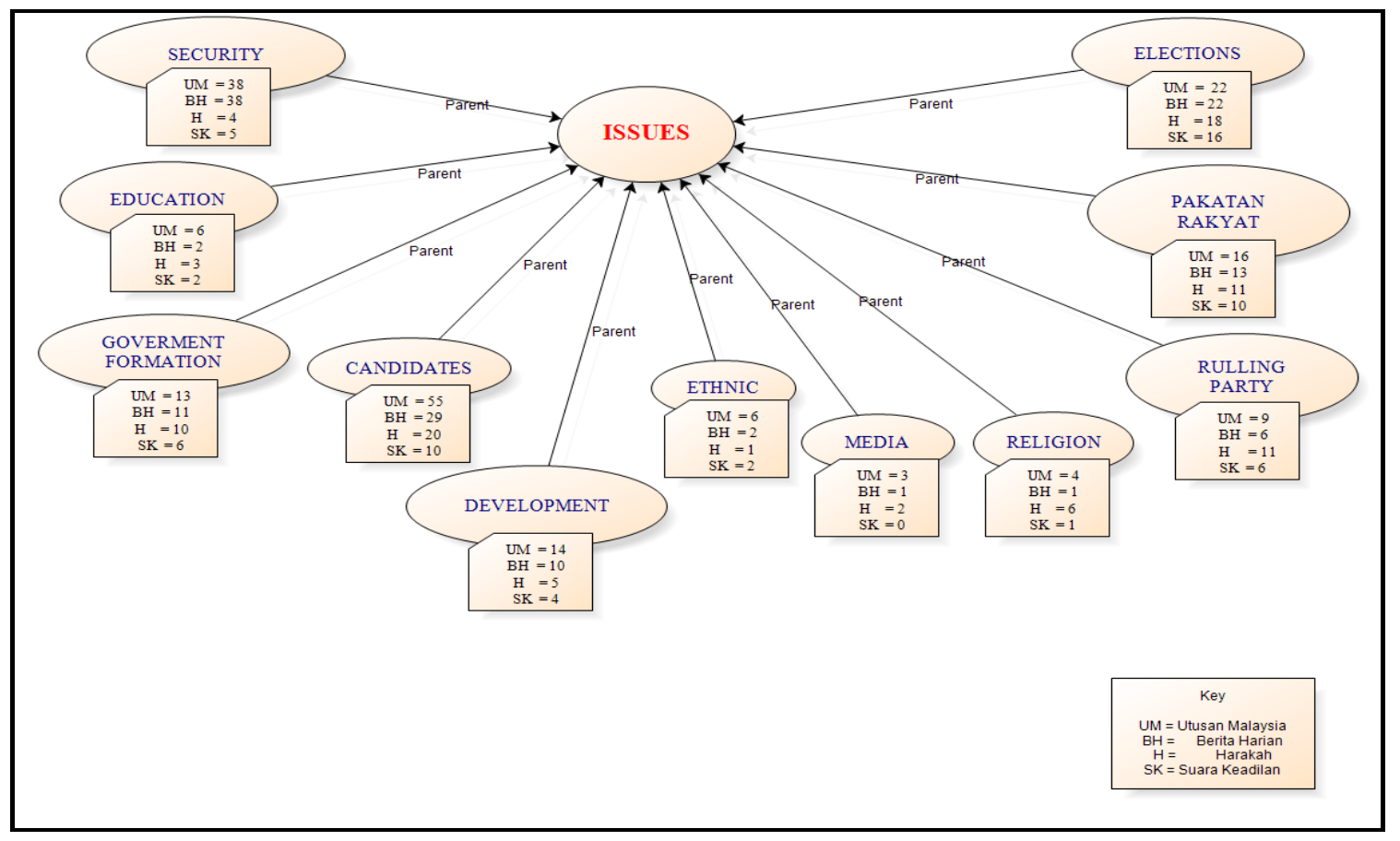

Figure 1. Pattern formation issues subcategories

The overall findings showed that the analysis 'tree nodes' that are used to study the issue very suited to be able to guide with more details on how the pattern formation of an issue. It was associated with framing theory applied in this study to find a detailed description of how a treatment of sub-instances of the issue is framed to an issue. This study supports the opinion of Chang, Musa, Ezhar, Syed Arabi and Lim (2009 which states that framing is the approach used to find out how the perspective or point of view and perspective of choosing issues that ultimately determine the facts are taken and highlighted.

Similarly, according to Tuchman (1978), framing approach in research content prior to reporting the news from the perspective of the real issue. This view was also supported by Kim, Scheuffele \& Shanahan (2002), which states a study should form a new issue because of the implications of the study indicate that the media framing pattern on pattern formation relevancy news and public perception formation.

Another use of framing theory is based on the results of the study found that there is a correlation with framing the issue in which this clearly through detailing the issues to sub-sub in order to make the reader think specifically and also able to explain about reporting the news so as to give effect to the reader. This supports the opinion of western scholars, stating the use of framing to find resources that framed the frame up to the description of how a time frame described an impact on society (Littlejohn, 2002). 


\section{Conclusion}

The use of framing theory in the study of issues has significant with the issues in the election. It is because of a significant release of this theory to explain in detail in order to make readers wondered how news develops. Based on studies conducted showed that this framing theory to explain treatment news published by the paper to be presented to the reader. It can be concluded that this study supports the views of scholars in framing news issues before the formulation of the issue for a comprehensive review of the results. This shows that the main issue presented relates to the framing theory that explains the issue into sub-issues before the next is framed and edited and shown to have an impact on voters. A news should form a new issue because of the implications of the study indicate that the media framing pattern on pattern formation relevancy news and public perception formation.

\section{References}

Bryant, J., \& Miron, D. (2004). Theory and research in mass communication. Journal of Communication, 54(4), 662-704. http://dx.doi.org/10.1111/j.1460-2466.2004.tb02650.x

Chang, P. K., Ahmad, F., \& Wan Mahmud, W. A. (2010). Knowledge of Content Analysis Framing Chedet Weblog. Com. Malaysian Journal of Communication, 26, 47-61.

Chang, P. K., Abu Hassan, M., Tamam, E., Idid, S. A., \& Lim, C. B. (2009, December 2-3). Contention between framing by media and framing through media. Paper to be presented at International Conference on Social Sciences and Humanities. Universiti Kebangsaan Malaysia.

Chang, P. K., Tan, J. L., \& Awang, M. Z. (2009). Framing information in advertisements Special Task Force to Facilitate Business. Journal Excellence, 1(1), 85-100.

Chong, D., \& Druckman, J. N. (2007a). A Theory of Framing and Opinion Formation in Competitive Elite Environments. Journal of Communication, 57, 99-118. http://dx.doi.org/10.1111/j.1460-2466.2006.00331.x

Chong, D., \& Druckman, J. N. (2007b). Framing Public Opinion in Competitive Democracies. American Political Science Review, 101(4), 637-655. http://dx.doi.org/10.1017/S0003055407070554

Chong, D., \& Druckman, J. N. (2007c). Framing Theory. Annual Review of Political Science, 10(1), 103-126. http://dx.doi.org/10.1146/annurev.polisci.10.072805.103054

D'Angelo, P. (2002). News framing as a multi-paradigmatic research program: A response to Entman. Journal of Communication, 52(4), 870-888. http://dx.doi.org/10.1111/j.1460-2466.2002.tb02578.x

Goffman, E. (1974). Frame Analysis: An Essay on the Organization of Experience. Cambridge, MA: Harvard University Press.

Kim, S. H., Scheufele, D. A., \& Shanahan, J. (2002). Think about it this way: Attribute agenda setting function of the press and the public's evaluation of a local issue. Journalism and Mass Communication Quarterly, 79, 7-25. http://dx.doi.org/10.1177/107769900207900102

Lee, K. T., \& Hashim, M. S. (2009). Media Framing of a Political Personality: A Case Study of a Malaysian Politician. European Journal of Social Sciences, 9(3), 408.

Littlejohn, S. W. (2002). Theories of human communication (7th ed.). Belmont: Wadsworth.

Saman, M. A. (1995). Writing \& Newspaper. Kuala Lumpur: Dewan Bahasa dan Pustaka.

Melissa, A. J., John, L., \& Sean, C. M. (2008). Mexican Expatriates Vote? Framing and Agenda Setting in U.S. News Coverage About Mexico. Communication and Society, 12, 4-25.

Nadeau, R., Petry, F., \& Bélanger, É. (2008). Strategic Issue Framing in Election Campaigns: The Case of Healthcare in the 2000 Canadian Federal Election. Paper presented at the annual meeting of the APSA August 2008 Annual Meeting, Hynes Convention Centre, Boston.

Reese, S. D. (2001). Prologue-Framing public life: A bridging model for media research. In S. D. Reese, O. H. Gandy, \& A. E. Grant (Eds.), Framing public life: Perspective on media and our understanding of the social world (pp. 7-31). Hillsdale: Erlbaum.

Scheff, T. J. (2005). The structure of context: Deciphering frame analysis. Sociological Theory, 23(4), 368-385. http://dx.doi.org/10.1111/j.0735-2751.2005.00259.x

Scheufele, D. A. (1999). Framing as a Theory of Media Effects. Journal of Communication, 49, 103-122. http://dx.doi.org/10.1111/j.1460-2466.1999.tb02784.x 
Scheufele, D. A. (2000). Agenda-setting, Priming, and Framing Revisited: Another Look at Cognitive Effects of Political Communication. Mass Communication \& Society, 3, 297-316. http://dx.doi.org/10.1207/S15327825MCS0323_07

Scheufele, D. A., \& David, T. (2007). Framing, Agenda Setting, and Priming: The Evolution of Three Media Effects Models. Journal of Communication, 57, 9-20.

Simon, A., \& Xenos, M. (2000). Media framing and effective public deliberation. Political Communication, 17, 363-376. http://dx.doi.org/10.1080/10584600050178979

Ardani, T. (2004). Rendering Issues in Indonesian Election: Content Analysis Research Newspapers Media Indonesia and Kompas. Master Thesis. Bangi: Universiti Kebangsaan Malaysia.

Thomas, E. N., Zoe, M. O., \& Rosalee, A. C. (1997). Toward A Psychology of Framing Effects. Political Bahavior, 19(3), 221-246. http://dx.doi.org/10.1023/A:1024834831093

Tuchman, G. (1978). Making news: A study in the construction of reality. New York: The FreePress.

Weaver, D. H. (2007). Thoughts on Agenda Setting, Framing, and Priming. Journal of Communication, 57(1), 142-147. http://dx.doi.org/10.1111/j.1460-2466.2006.00333.x

\section{Copyrights}

Copyright for this article is retained by the author(s), with first publication rights granted to the journal.

This is an open-access article distributed under the terms and conditions of the Creative Commons Attribution license (http://creativecommons.org/licenses/by/3.0/). 